\title{
ANALISIS PERUBAHAN BESARAN LISTRIK PADA PEMANAS INDUKSI MENGGUNAKAN INVERTER SETENGAH JEMBATAN
}

\author{
Sandy Anggara ${ }^{1}$, Afriyastuti Herawati ${ }^{1}$, Irnanda Priyadi ${ }^{1}$, Ika Novia Anggraini ${ }^{1}$ \\ ${ }^{1}$ Program Studi Teknik Elektro Universitas Bengkulu, rasya.hera@gmail.com
}

\begin{abstract}
ABSTRAK
Nowadays induction heating has become one of the people's choices in the heating process both in industry and households. Induction heating technology is also growing. But the electrical quantities that change with the temperature changes in the induction heating process must also be analyzed. To make induction heating, we need a device that is capable of producing large electrical energy. This tool uses a 12 Volt DC voltage, strong current 10 ampere and with a 120 watt input power. This induction heater is made using a half bridge inverter which generates heat through waves at high frequencies. The resonant frequency used is $25 \mathrm{kHz}$. From the test obtained an average temperature increase of $134.5^{\circ} \mathrm{C}$ at the 600th second with a paper clip load and with a voltage of 3.33 Volts, a current of $0.15 \mathrm{~A}$, a power of 0.56 watts, and a heat of $19.5 \mathrm{~J}$, and a test with a load nails obtained an average temperature of

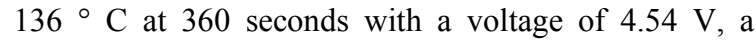
current of $0.27 \mathrm{~A}$, power of 1.12 watts, and a heat of $33.6 \mathrm{~J}$
\end{abstract}

Kata kunci : Pemanas Induksi, frekuensi, suhu, Solenoide.

\section{PENDAHULUAN}

Di Indonesia dalam kehidupan sehari-hari sering dilakukan kegiatan pemanasan logam sampai meleburkan logam dalam kegitan tersebut tentunya dibutuhkan suatu alat yang dapat menghasilkan panas. Panas yang dibutuhkan untuk kegiatan tersebut dapat dihasilkan dari pembakaran minyak bumi, gas ataupun kayu.

Seiring perkembangan zaman kegiatan seperti itu dengan menggunakan kayu bakar dan minyak bumi sudah hampir ditinggalkan, karena proses pembakaran menggunakan minyak bumi atau kayu menimbulkan polusi yang banyak, dan perlu diketahui minyak bumi merupakan suatu bahan bakar yang tidak dapat diperbaharui, artinya semakin sering dipakai maka ketersediannya akan semakin berkurang, dan proses terbentuknya minyak bumi memerlukan waktu yang sangat lama selain itu pemanasan yang dilakukan dengan bahan bakar minyak bumi, gas, ataupun kayu bakar akan menimbulkan api.

Sumber energi alternatif untuk pemanasan sangat diperlukan dalam kegiatan masak-memasak, memanaskan air, dan meleburkan logam agar dapat menghemat bahan bakar dan menambah faktor keselamatan sehingga dapat mengurangi resiko kecelakaan. Oleh karena hal tersebut diperlukan suatu metode pemanasan yang lebih aman dan cepat. Salah satu cara untuk mengatasi masalah tersebut ialah dengan menggunakan metode pemanasan secara induksi.

Proses pemanasan secara induksi membutuhkan frekuensi tinggi sehingga dibutuhkan catu daya yang digunakan untuk mensupply pemanas induksi tersebut. Dalam penelitian ini akan dirancang inverter frekuensi tinggi dengan topologi inverter setengah jembatan yang dapat menghasilkan listrik bolak balik dengan frekuensi yang tinggi.

Inverter memiliki peranan penting dalam pemanfaatan menghasilkan listrik bolak balik dengan frekuensi yang tinggi. Inverter ini mengkonversi tegangan DC menjadi AC dengan metode penyaklaran tertentu.

Pada proses pemanasan menggunakan pemanas induksi maka akan terjadi perubahan besaran-besaran listrik baik itu tegangan, arus maupu daya nya. Perubahan ini akan terjadi seiring dengan perubahan frekuensi kerja dari pemanas induksi tersebut. Perubahan pada besaran-besaran ini sangat penting untuk dianalisis untuk mendapatkan karakteristik kerja dari pemanas induksi ini.

Pemanas induksi yang berbasis elektronika daya memiliki keterkaitan erat dengan frekuensi kerja, nilai tegangan dan arus masukan, dan bentuk benda yang akan dipanaskan. Masing-masing faktor tersebut memiliki pengaruh terhadap karakteristik panas yang dihasilkan. Dengan elektronika daya, faktor-faktor tersebut dapat diubah nilainya sehingga memungkinkan untuk pengujian karakteristik panas. Selain perancangan dan pembuatan pemanas induksi ini, penelitian akan dilakukan dengan mengubah-ubah besaran tertentu seperti beban dan arus masukan dan dikaitkan pengaruhnya terhadap suhu yang dihasilkan pemanas induksi. 


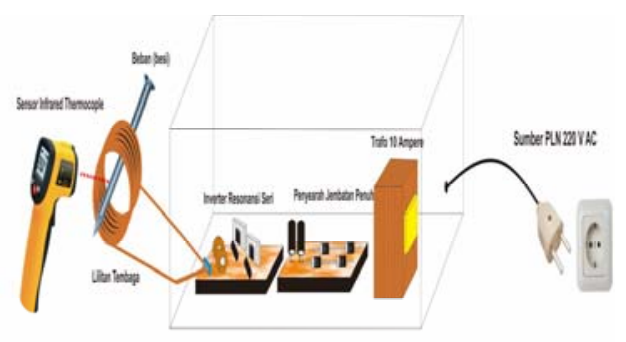

Gambar 2.1Komponen-komponen Pemanas Induksi[3]

\section{TINJAUAN PUSTAKA}

\section{Pemanas Induksi}

Pemanas induksi adalah salah satu teknik pemanasan logam dengan cara mengalirkan listrik arus bolak-balik dengan frekuensi yang tinggi pada kumparan kerja, sehingga pada kumparan kerja tersebut terbentuk ggl yang digunakan untuk meng-induksi suatu logam [3].

\section{Komponen Pemanas Induksi}

1. Benda kerja yang dipanasi berupa bahan feromagnetik seperti besi, baja, dan logamdengan ketebalan yang disesuaikan.

2. Elemen pemanas yang digunakandibuat dari bahan tembaga yaitu jenis lilitan tembaga, lilitan tembagadibuat dari bahan tembaga yang baik dalam mengalirkan arus listrik, dengan diameter $2.5 \mathrm{~mm}$. Setelah dililit menyesuaikan dengan dimensi benda kerja didapatkan 10 lilitan.

3. Frekuensi resonansi untuk pemanas pada 20 sampai $50 \mathrm{kHz}$.

4. MOSFET digunakan sebagai saklar elektronik.

5. Keluaran dari MOSFET dihubungkan ke lilitan tembaga (coil).

6. Lilitan tembaga (coil) merupakan tempat munculnya medan magnet frekuensi tinggi yang akan menginduksi benda kerja.

7. Benda kerja berupa bahan feromagnetikyang dikenai medan induksi dan kemudian muncul panas pada benda kerja tersebut.

Frekuensi kerja yang telah di tentukan dapat diatur dengan menggunakan nilai kapasitor dengan cara menggunakan persamaan 2.2. dan 2.3. [3].

$$
\mathrm{f}_{\mathrm{u}}=\frac{1}{2 \pi \sqrt{L \cdot C}}
$$

\footnotetext{
Dimana:

$\mathrm{f}_{\mathrm{u}} \quad=$ frekuensi resonansi $(\mathrm{kHz})$

$\mathrm{L} \quad=$ induktansi $(\mu \mathrm{H})$

$\mathrm{C} \quad=$ kapasitansi $(\mu \mathrm{F})$
}

$$
\mathrm{C}=\frac{1}{\left(2 \pi \cdot f_{u}\right)^{2} \cdot L}
$$

Dimana:

$\mathrm{f}_{\mathrm{u}} \quad=$ frekuensi resonansi $(\mathrm{kHz})$

$\mathrm{L} \quad=$ induktansi $(\mu \mathrm{H})$

$\mathrm{C} \quad=\operatorname{kapasitansi}(\mu \mathrm{F})$

\section{Ukuran Pemanasan Dari Pemanas Induksi}

Salah satu yang penting dari desain pemanas induksi ini adalah hasil pengukuran pemanasan yang berupa panas (kalor). Dengan mengetahui ukuran pemanasan yang dihasilkan, maka kita dapat memperkirakan apakah alat ini dapat diterapkan pada dunia industri sekarang ini. Hal ini bergantung pada beberapa faktor antara lain desain pemanas induksi tersebut dan kapasitas dari sumber AC yang digunakan pada pemanas induksi. Apabila suhu pada inti besi yang telah terhubung pada sumber AC terjadi kenaikan, maka pemanas induksi ini dapat dikatakan sudah dapat berfungsi dengan baik. Kenaikan suhu yang terjadi pada inti besi tersebut disebabkan oleh rugi-rugi arus eddy.

Satuan dari kalor adalah kalor memiliki hubungan dengan energi mekanik, dimana satuan energi mekanik adalah joule sehingga telah ditetapkan dari hukum kekekalan energi bahwa : 1 kalori $=4,186$ joule. Setelah kita mengetahui kalor yang dihasilkan, maka kita dapat mengetahui kapasitas dari kalor yang dihasilkan tersebut dengan persamaan 2.4 sebagai berikut[17].

$$
\mathrm{C}_{\mathrm{P}}=\frac{Q}{m \cdot \Delta T}
$$

Dengan:

$$
\begin{array}{ll}
\mathrm{C}_{\mathrm{p}} & =\text { kalor jenis besi }\left(448 \mathrm{~J} / \mathrm{kg} \cdot{ }^{\circ} \mathrm{C}\right) \\
\mathrm{Q} & =\text { Kalor }(\text { kalori }) \\
\mathrm{m} & =\text { massa }(\mathrm{kg}) \\
\Delta \mathrm{T} & =\text { kenaikan Suhu }\left({ }^{\circ} \mathrm{C}\right)
\end{array}
$$

Kalor yang telah diketahui akan diubah ke energi mekanik dengan joule, yaitu untuk mengetahui perbandingan daya yang dihasilkan dari rugi-rugi arus eddy dengan daya yang dihasilkan dari kalor maka satuan joule tersebut dibagi dengan waktu yang digunakan untuk pemanasan. Maka digunakan persamaan 2.5 dan rumus kenaikan suhu pada persamaan 2.6 [17].

$$
\mathrm{P}=\frac{Q}{\mathrm{t}}
$$

Sehingga: $\mathrm{Q}=\mathrm{P} \times \mathrm{t}$

Dengan : 


$$
\begin{array}{ll}
\mathrm{P} & =\text { Daya (watt) } \\
\mathrm{Q} & =\text { kalor yang dihasilkan (joule) } \\
\mathrm{t} & =\text { waktu (detik) }
\end{array}
$$

$$
\Delta \mathrm{T}=\frac{P . t}{m \cdot C_{P}}
$$

Dengan :

$\Delta \mathrm{T} \quad=$ kenaikan suhu $\left({ }^{\circ} \mathrm{C}\right)$

$\mathrm{P} \quad=$ daya (watt)

$\mathrm{t} \quad=$ waktu (detik)

$\mathrm{m} \quad=$ massa $(\mathrm{kg})$

$\mathrm{C}_{\mathrm{P}} \quad=$ massa jenis besi $\left(448 \mathrm{~J} / \mathrm{kg} .{ }^{\circ} \mathrm{C}\right)$

Demikian persamaan yang digunakan dimana kalor yang dihasilkan berbanding selisih waktu yang diperoleh. [17].

\section{Rangkaian Toroid}

Pada alat pemanas induksi ini juga digunakan kumparan toroid pada rangkaian daya, dimana toroid adalah solenoida yang dilengkungkan sehingga sumbunya menjadi berbentuk lingkaran. Induktor yaitu komponen elektronika berbentuk kumparan yg tersusun dari lilitan kawat. Induktor adalah salah satu di antara komponen pasif elektronika yg dapat membuahkan medan magnet apabila dialiri arus listrik \& sebaliknya bila di beri medan magnet dapat membuahkan listrik. Induktor $(\mu \mathrm{H})$ dibuat dari lilitan toroid. Induktor pada toroid merupakan sebuah kumparan yang memiliki Induktansi (L) yang signifikan. Dimana untuk mencari nilai L maka digunakan persamaan 2.7. Sedangkan rumus perhitungan daya dan daya yangdihasilkan dapat dilihat pada persamaan 2.8 dan $2.9[17]$,[8].

$$
\mathrm{L}=\frac{\mu \circ \cdot N^{2} . A}{l}
$$

Dimana :

$$
\begin{array}{ll}
\mathrm{L} & =\text { induktansi } \\
\mathrm{N} & =\text { Jumlah lilitan } \\
\mathrm{A} & =\text { Luas penampang } \\
\mathrm{l} & =\text { panjang kumparan. }
\end{array}
$$

$$
\mathrm{P}=\mathrm{V} \times \mathrm{I}
$$

Dimana :

$$
\begin{array}{ll}
\mathrm{P} & =\text { daya (watt) } \\
\mathrm{V} & =\text { Tegangan (Volt) } \\
\mathrm{I} & =\text { Arus (Ampere) } \\
& \mathrm{P}_{\mathrm{m}}=4,17 \times \text { m.c } \times \frac{\Delta T}{\Delta t}
\end{array}
$$

Dimana :

$$
\begin{array}{ll}
\mathrm{m} & =\text { massa }(\mathrm{kg}) \\
\mathrm{c} & =\text { Kalor jenis besi }\left(\mathrm{J} / \mathrm{kg}^{\circ} \mathrm{C}\right) \\
\Delta \mathrm{T} & =\text { Suhu }\left({ }^{\circ} \mathrm{C}\right) \\
\Delta \mathrm{t} & =\text { Waktu (detik) }
\end{array}
$$

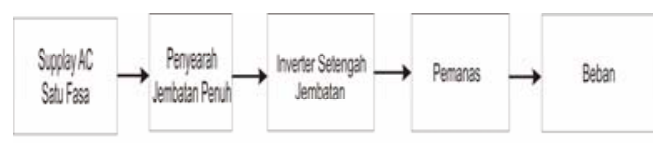

Gambar 1. Diagram blok pemanas induksi setengah jembatan

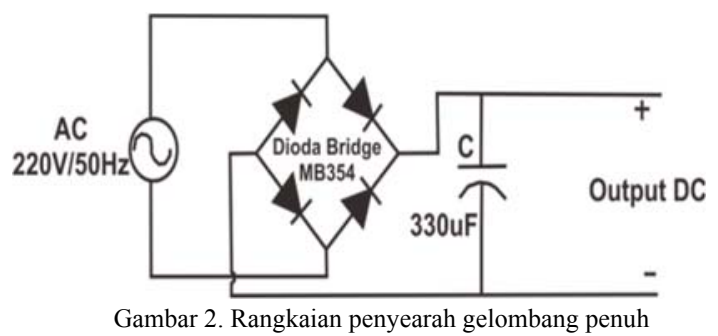

\section{METODE RISET}

\section{Rancangan Penelitian}

Penelitian ini akan dilakukan perancangan dan pembuatan pemanas induksi menggunakan MOSFET inverter setengah jembatan. Hardware yang akan dirancang merupakan suatu rangkaian power supply dan MOSFET dengan rangkaian resonansi dengan frekuensi tinggi yang dapat bekerja secara optimal untuk dihubungkan dengan pemanas agar dapat menghasilkan induksi elektromagnetik yang diinginkan. Keseluruhan sistem dari perancangan alat pengendali ini ditunjukkan dalam diagram blok pada Gambar 1 .

Secara umum perancangan alat yang akan dilakukan yaitu suplai AC satu fasa $220 \mathrm{~V}$ akan disearahkan sebagai sumber bagi inverter. Kemudian hasil keluaran dari penyearah yang berupa gelombang DC akan di ubah menjadi gelombang AC melalui inverter. Keluaran inverter ini kemudian yang akan menjadi sumber bagi pemanas induksi dengan inverter setengah jembatan frekuensi $25 \mathrm{kHz}$. Setelah itu akan dilakukan evaluasi dan analisis terhadap besaranbesaran pada pemanas induksi ini.

\section{Penyearah Gelombang Penuh}

Penyearah gelombang penuh ini digunakan untuk menyearahkan tegangan AC menjadi DC untuk suplai masukan pada rangkaian inverter (Gambar 2).

Penyearah gelombang penuh ini menggunakan dioda bridge MB354 yang akan mengubah tegangan $220 \mathrm{~V}$ ac menjadi $12 \mathrm{~V}$ dc. Penyearah ini menggunakan dioda bridge MB354 karena lebih efisien dan sesuai untuk rancangan rangkaian yang digunakan, range tegangan dan arus pada dioda bridge MB354 yaitu 50 sampai 1000 Volt dan 35.0 Ampere dan digunakan kapasitor $330 \mu \mathrm{F}$ untuk menghaluskan gelombang keluaran hasil penyearahan. 


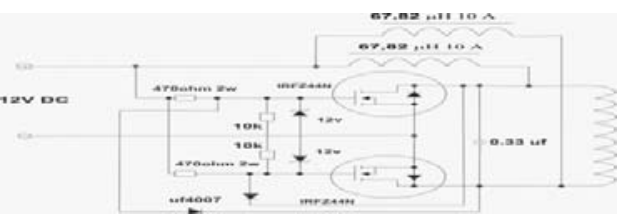

Gambar 3. Rangkaian invertersetengah jembatan

\section{Rangkaian Inverter Setengah Jembatan}

Perancangan rangkaian MOSFET dengan rangkaian inverter setengah jembatan terdiri dari beberapa bagian yaitu rangkaian resonansi dan MOSFET (Gambar 3).

Pada MOSFET dengan rangkaian setengah jembatan ini menggunakan type MOSFET IRFZ44Nkarena MOSFET jenis ini mempunyai kestabilan tegangan yang cukup baik karena tegangan masukan sama dengan tegangan keluaran. MOSFET berfungsi sebagai penguat tegangan dan sebagai saklar. Pada rangkaian ini digunakan MOSFET IRFZ44N. Pemilihan MOSFET ini karena dapat menerima tegangan masukan hingga 55 Volt DC dan arus maksimal hingga 49 Ampere.

Pada penelitian ini akan digunakan frekuensi resonansi sebesar $25 \mathrm{kHz}$. Frekuensi resonansi dapat ditentukan dengan cara mengatur nilai kapasitor dan dengan diketahuinya nilai induktansi yang akan digunakan pada rangkaian. Nilai kapasitor yang dapat digunakan untuk mengatur frekunsi yang dinginkan dapat menggunakan rumus pada persamaan 2.2.

Untuk frekuensi $25 \mathrm{kHz}$ maka nilai kapasitor yang dibutuhkan :

$$
\begin{aligned}
& \mathrm{C}=\frac{(1)}{\left(2 \pi \cdot 25 \cdot 10^{3}\right)^{2} \cdot 0,067 \cdot 10^{-3}} \\
& \mathrm{C}=605,51 \mathrm{nF}
\end{aligned}
$$

\section{Rangkaian Pengujian Pemanas Induksi}

Rangkaian yang digunakan pada perancangan pemanas induksi inverter setengah jembatan adalah rangkaian power supply gelombang penuh yang disupply menggunakan trafo 10 A dengan tegangan AC 12 Volt, kemudian rangkaian power supply dihubungkan dengan rangkaian inverter setengah jembatan, rangkaian inverter setengah jembatan menggunakan 2 MOSFET IRFZ44N, 2 buah Kapasitor $0,33 \mu \mathrm{F}, 2$ buah induktor toroid $67,8 \mu \mathrm{H}$ yang disupply oleh power supply gelombang penuh dengan tegangan 12 V DC. Selanjutnya rangkaian inverter setengah jembatan dihubungkan ke lilitan tembaga. Gambar rangkaian pengujian pemanas induksi setengah jembatan dapat dilihat pada Gambar 4.

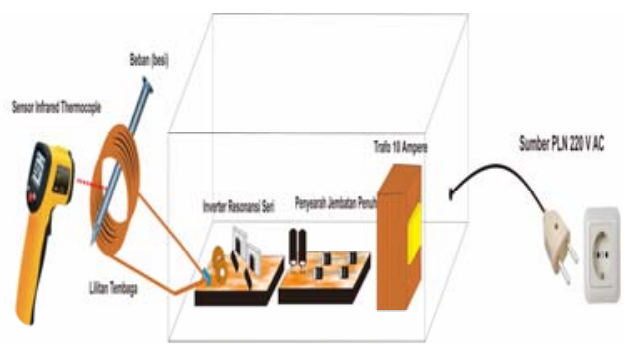

Gambar 4. Rangkaian Pengujian Pemanas induksi

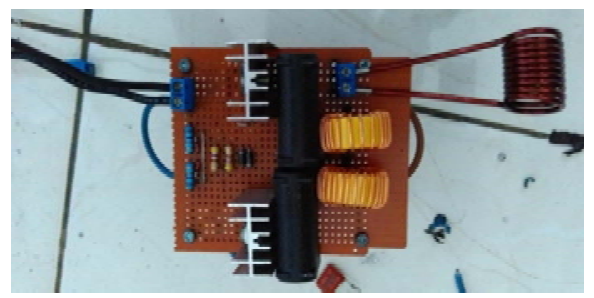

Gambar 5 Rangkaian inverter setengah jembatan

\section{HASIL DAN PEMBAHASAN}

\section{Inverter Setengah Jembatan}

Rangkaian inverter setengah jembatan di buat dengan menggunakan MOSFET IRFZ44N yang digunakan sebanyak 2 buah agar mendapatkan keluaran yang diinginkan.

Rangkaian inverter pada alat pemanas induksi ini merupakan rangkaian yang mampu untuk mengkonversi besaran listrik dari searah menjadi besaran komponen daya yaitu MOSFET, dioda, induktor.

Hasil dari perancangan inverter setengah jembatan dapat dilihat pada gambar 5 yaitu gambar inverter setengah jembatan..

Pada gambar 5 rangkaian inverter setengah jembatan menggunakan 2 buah MOSFET yang digunakan, MOSFET yang digunakan akan bekerja sebagai switching.

Rangkaian inverterdi supply oleh penyearah gelombang penuh dengan tegangan 12 Volt DC. Keluaran rangkaian inverter kemudian dihubungkan ke rangkaian resonansi sebelum dihubungkan pada lilitan tembaga pada pemanas induksi.

\section{Pengamatan gelombang tegangan output Rangkaian Resonansi}

Pada pemanas induksi inverter setengah jembatan dilakukan pengujian dengan melihat gelombang keluaran yang didapatkan dari rangkaian reonansi. Pengujian untuk melihat gelombang keluaran dari rangkaian resonansi diuji dengan menggunakan osiloskop. Hasil gelombang yang didapat pada rangkaian resonansi dapat dilihat pada Gambar 6. 


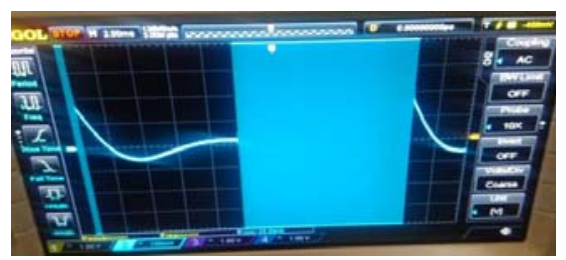

Gambar 6 Gelombang output rangkaian resonansi

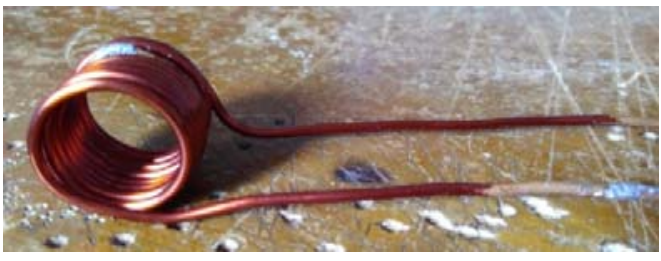

Gambar 7 lilitan tembaga pemanas induksi.

Pada Gambar 6 dapat dilihat hasil gelombang keluaran dari rangkaian resonansi, dari Gambar 6 dapat dilihat gelombang keluaran yang masih belum sempurna, masih terdapat riak yang cukup besar pada gelombang rangkaian resonansi seperti yang terlihat pada Gambar 6. Riak yang didapatkan diakibatkan masih kurang baiknya rangkaian filter yang digunakan pada rangkaian pemanas induksi ini sehingga mendapatkan riak yang cukup besar pada gelombang resonansi. Pada gelombang resonansi dapat dilihat didapatkan frekuensi sebesar $25 \mathrm{kHz}$ pada osiloskop.

Berdasarkan hasil dari perhitungan nilai frekuensi dengan menghitung nilai kapasitor yang dibutuhkan maka dapat disimpulkan bahwa semakin besar frekuensi yang di inginkan maka kapasitor yang dibutuhkan semakin kecil.

\section{Lilitan Tembaga Pemanas Induksi}

Pemanas induksi pada penelitian ini menggunakan lilitan tembaga yang digunakan sebagai tempat terjadinya pemanasan induksi yang diakibatkan medan elektromagnetik menggunakan kawat tembaga yang berukuran $2,5 \mathrm{~mm}$. Lilitan tembaga yang digunakan dililit sebanyak 10 lilitan dengan ukuran panjang lilitannya hingga $2,8 \mathrm{~cm}$ dan panjang dan panjang kawat sekitar $8 \mathrm{~cm}$. Gambar dari lilitan tembaga dapat dilihat pada Gambar 7

\section{Rangkaian Keseluruhan Pemanas Induksi}

Pada penelitian ini perancangan bentuk untuk pemanas induksi dibuat dengan menggunakan tembaga yang telah dirancang untuk dapat menghasilkan panas yang diharapkan.

Pada perancangan pemanas induksi ini dihubungkan dari rangkaian-rangkaian yang telah dibuat

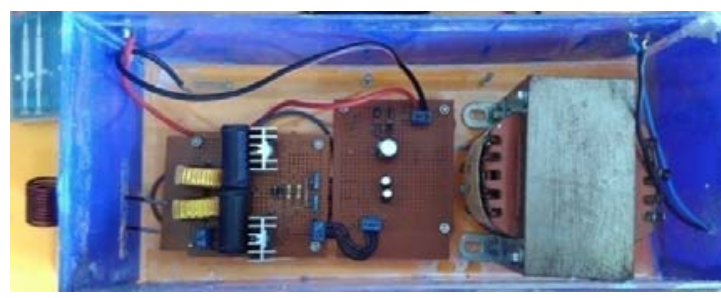

Gambar 8 Rangkaian pemanas induksi secara keseluruhan.

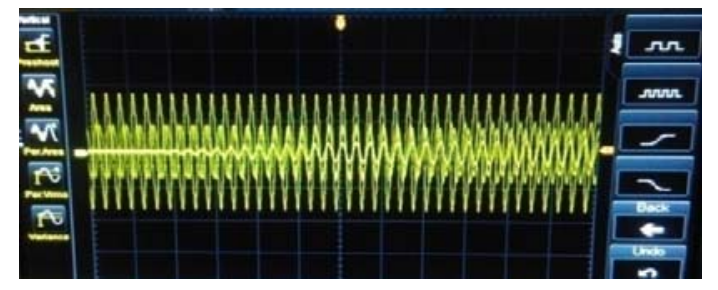

Gambar 9. Gelombang keluaran osiloskop dengan beban klip kertas.

yang selanjutnya dihubungkan pada pemanas induksi.

Pada proses ini kumparan yang dialiri arus listrik bolak-balik frekuensi tinggi akan menghasilkan medan magnet yang akan menginduksi badan/elemen pemanas pada beban Pada beban akan terbentuk arus eddydan rugi histerisis yang akan menimbulkan panas. Panas inilah yang nantinya digunakan untuk memanaskan bahan yang diinginkan. Adapun Gambar 8 adalah gambar bentuk rangkaian keseluruhan dari pemanas induksi.

\section{Pengujian Pemanas Induksi}

Rancang bangun alat pemanas induksi menggunakan solenoide ini akan dapat dikatakan berhasil apabila sudah menghasilkan panas, dan panas tersebut dapat digunakan untuk memanaskan bahan yang digunakan. Dalam pengujian pemanas induksi ini dilakukan pemanasan terhadap beberapa inti besi yang berbeda ukurannya.

Dari data pengujian tegangan, arus, dan daya pada Tabel 4.4 didapatkan data dengan tegangan pada detik ke-30 sebesar 7,03 Volt dan arus sebesar 0,32 Ampere dan daya 2,24 Watt, diukur hingga mencapai detik ke-600 dengan tegangan sebesar 3,33 Volt dan arus sebesar 0,15 Ampere dan daya 0,53 Watt. Dari hasil data yang didapatkan dapat disimpulkan bahwa tegangan dan dan daya yang dihasilkan semakin menurun terhadap lama waktu pemanasan, sementara arus yang didapatkan cukup konstan.

Setelah dilakukan pengujian tegangan, arus, dan daya yang dihasilkan maka dapat dilihat hasil gelombang keluaran pemanas induksi pada osiloskop dengan menggunakan beban klip kertas. Gelombang keluaran hasil pengujian dengan beban klip kertas dapat dilihat pada Gambar 9. 
Tabel 1 Data Hasil Pengujian Tegangan, Arus, dan Daya dengan beban Paku.

\begin{tabular}{lllll}
\hline $\begin{array}{l}\text { Waktu } \\
(\mathrm{s})\end{array}$ & $\begin{array}{l}\text { Tegangan } \\
(\mathrm{V})\end{array}$ & Arus (A) & $\begin{array}{l}\text { Daya } \\
(\mathrm{W})\end{array}$ & $\begin{array}{l}\text { Energi } \\
(\mathrm{J})\end{array}$ \\
\hline 30 & 7,05 & 0,52 & 3,66 & 109,8 \\
60 & 7,01 & 0,42 & 2,96 & 88,8 \\
90 & 6,03 & 0,26 & 1,56 & 46,8 \\
120 & 5,57 & 0,23 & 1,28 & 38,4 \\
150 & 5,33 & 0,21 & 1,11 & 33,3 \\
180 & 5,01 & 0,24 & 1,2 & 36 \\
210 & 5,2 & 0,25 & 1,19 & 35,7 \\
240 & 5,33 & 0,23 & 1,15 & 34,5 \\
270 & 4,92 & 0,27 & 1,17 & 35,1 \\
300 & 4,84 & 0,28 & 1,17 & 35,1 \\
330 & 4,56 & 0,29 & 1,15 & 34,5 \\
360 & 4,54 & 0,27 & 1,15 & 34,5 \\
\hline
\end{tabular}

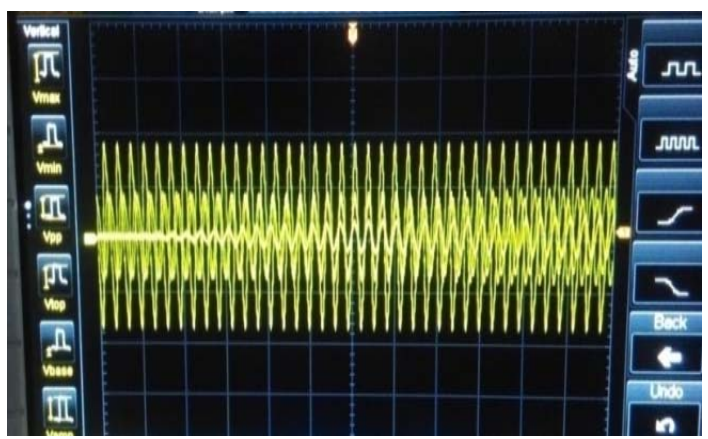

Gambar 10. Gelombang keluaran osiloskop dengan beban paku.

\section{Pengujian Tegangan, Arus, dan Daya dengan beban Paku}

Setelah dilakukan pengujian pemanas induksi dengan kenaikan suhu yang di dapat, maka dilakukan pengujian berapa besar tegangan, arus, dan daya yang digunakan pada saat melakukan pemanasan. Data hasil pengujian tegangan, arus dan daya yang dilakukan pada pemanas induksi dapat dilihat pada tabel 1 .

Dari data pengujian tegangan, arus, dan daya pada Tabel 1 didapatkan data dengan tegangan pada detik ke-30 sebesar 7,05 Volt dan arus sebesar 0,52 Ampere dan daya 3,66 Watt, diukur hingga mencapai detik ke-360 dengan tegangan sebesar 4,54 Volt dan arus sebesar 0,27 Ampere dan daya 1,15 Watt. Dari hasil data yang didapatkan dapat disimpulkan bahwa tegangan dan dan daya yang dihasilkan semakin menurun terhadap lama waktu pemanasan, sementara arus yang didapatkan cukup konstan.

Setelah dilakukan pengujian tegangan, arus, dan daya yang dihasilkan maka dapat dilihat hasil gelombang keluaran pemanas induksi pada osiloskop dengan menggunakan beban paku. Gelombang keluaran hasil pengujian dengan beban paku dapat dilihat pada Gambar 10.

\begin{tabular}{lllll}
\multicolumn{5}{c}{ Tabel 2 Data Hasil Pengujian Tegangan, Arus, dan Daya tanpa Beban. } \\
\hline $\begin{array}{llll}\text { Waktu } \\
(\mathrm{s})\end{array}$ & $\begin{array}{l}\text { Tegangan } \\
(\mathrm{V})\end{array}$ & Arus $(\mathrm{A})$ & $\begin{array}{l}\text { Daya } \\
(\mathrm{W})\end{array}$ & $\begin{array}{l}\text { Energi } \\
(\mathrm{J})\end{array}$ \\
\hline 30 & 7,05 & 1,21 & 7,01 & 210,3 \\
60 & 7,03 & 1,22 & 6,54 & 196,2 \\
90 & 6,63 & 1,26 & 6,54 & 196,2 \\
120 & 6,57 & 1,23 & 6,23 & 186,9 \\
150 & 6,33 & 0,91 & 6,75 & 202,5 \\
180 & 6,11 & 0,94 & 5,76 & 172,8 \\
210 & 6,23 & 0,95 & 5,48 & 164,4 \\
240 & 6,30 & 0,93 & 5,76 & 172,8 \\
270 & 6,45 & 1,19 & 6,13 & 183,9 \\
300 & 6,50 & 1,10 & 6,17 & 185,1 \\
330 & 6,52 & 1,15 & 6,15 & 184,5 \\
360 & 6,51 & 1,13 & 6,16 & 184,8 \\
390 & 6,24 & 1,09 & 6,13 & 183,9 \\
420 & 6,21 & 1,08 & 6,10 & 183 \\
450 & 6,57 & 1,05 & 6,25 & 187,5 \\
480 & 6,47 & 1,10 & 6,24 & 187,2 \\
510 & 6,34 & 1,11 & 6,14 & 184,2 \\
540 & 6,24 & 1,13 & 6,13 & 183,9 \\
570 & 6,12 & 1,09 & 6,10 & 183 \\
600 & 6,11 & 1,07 & 6,09 & 182,7 \\
\hline & & & & \\
\hline
\end{tabular}

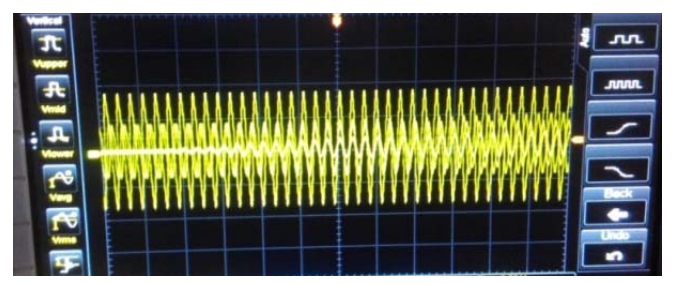

Gambar 11. Gelombang keluaran osiloskop tanpa beban.

\section{Pengujian Tegangan, Arus, dan Daya tanpa Beban}

Setelah dilakukan pengujian pemanas induksi dengan kenaikan suhu yang di dapat, maka dilakukan pengujian berapa besar tegangan, arus, dan daya yang digunakan pada saat melakukan pemanasan. Data hasil pengujian tegangan, arus dan daya yang dilakukan pada pemanas induksi dapat dilihat pada tabel 2 .

Dari data pengujian tegangan, arus, dan daya tanpa beban pada Tabel 2 dapat dilihat bahwa tegangan yang didapat pada detik ke-30 sebesar 7,05 Volt dan arus sebesar 1,21 Ampere dan daya 7,01 Watt, diukur hingga mencapai detik ke-600 dengan tegangan sebesar 6,11Volt dan arus sebesar 1,07 Ampere dan daya 6,09 Watt. Dari hasil data yang didapatkan dapat disimpulkan bahwa tegangan dan dan daya yang dihasilkan hanya mengalami sedikit penurunan tapi tetap konstan terhadap lama waktu pemanasan, sementara arus yang didapatkan cukup juga konstan.

Setelah dilakukan pengujian tegangan, arus, dan daya yang dihasilkan dengan menggunakan 


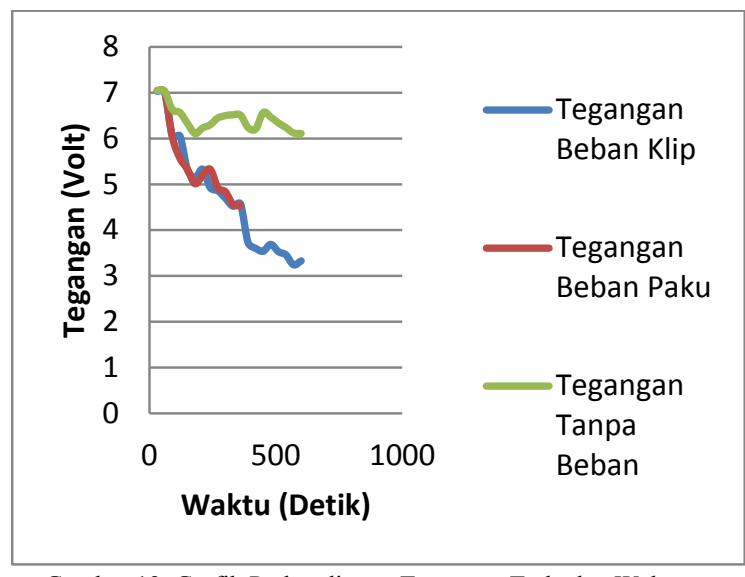

Gambar 12. Grafik Perbandingan Tegangan Terhadap Waktu.

pemanas induksi, maka dapat dilihat hasil gelombang keluaran hasil pemanas induksi pada osiloskop dengan melakukan pengujian tanpa beban. Gelombang keluaran hasil pengujian tanpa beban dapat dilihat pada Gambar 11.

Setelah dilakukannya pengukuran tegangan, arus, daya, dan kalor yang dilakukan terhadap lamanya waktu pemanasan pemanas induksi didapatkan hasil gelombang osiloskop yang dapat dilihat pada Gambar 12, 13, dan 14, dapat dilihat dari hasil gelombang osiloskop yang didapatkan tidak terlalu jauh berbeda karena hasil pengujian dari ketiga percobaan juga tidak terlalu berbeda dari masing-masing percobaan dengan klip kertas, paku dan tanpa beban, dan dari hasil pengujian tegangan, arus, daya, dan kalor yang dilakukan, didapatkan nilai yang tidak terlalu jauh berbeda juga dari masing-masing rumus yang digunakan.

Setelah dilakukannya pengujian tegangan, arus dan daya dengan menggunakan beban klip kertas, beban paku dan tanpa beban, dapat dilihat grafik perbandingan tegangan, arus dan daya dengan pengujian klip kertas, paku, dan tanpa beban pada Gambar 12.

Dari Gambar 12 grafik perbandingan tegangan terhadap waktu dengan menggunakan beban klip kertas, beban paku, dan tanpa beban dapat dilihat bahwa dari pengujian klip kertas dan paku tegangan mengalami penurunan dengan semakin lamanya waktu yang digunakan pada saat pemanasan. Sedangkan tegangan tanpa beban hanya mengalami sedikit penurunan dalam lamanya waktu pemanasan, dapat diartikan bahwa beban yang digunakan berpengaruh terhadap tegangan yang didapatkan pada saat pemanasan.

Setelah dilakukannya pengujian tegangan, arus dan daya dengan menggunakan beban klip kertas, beban paku dan tanpa beban, dapat dilihat grafik perbandingan tegangan, arus dan daya dengan pengujian klip kertas, paku, dan tanpa beban pada Gambar 13.

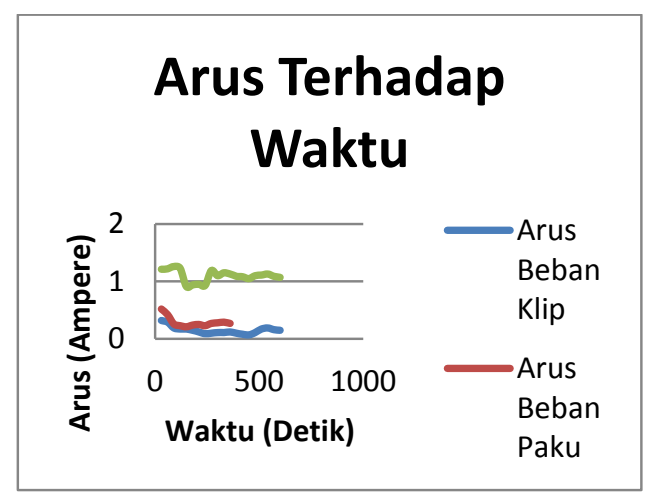

Gambar 13. Grafik Perbandingan Arus Terhadap Waktu.

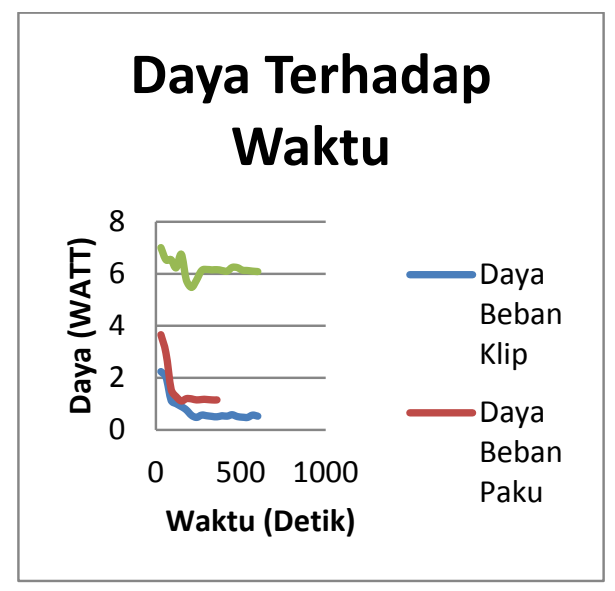

Gambar 14. Grafik Perbandingan Daya Terhadap Waktu.

Dari Gambar 13 grafik perbandingan arus terhadap waktu dengan menggunakan beban klip kertas, beban paku, dan tanpa beban dapat dilihat bahwa dari pengujian klip kertas dan paku arus mengalami sedikit penurunan dengan semakin lamanya waktu yang digunakan pada saat pemanasan. Sedangkan arus tanpa beban hanya mengalami sedikit penurunan dan cukup konstan dalam lamanya waktu pemanasan, dapat diartikan bahwa beban yang digunakan berpengaruh terhadap tegangan yang didapatkan pada saat pemanasan.

Dari hasil grafik pada Gambar 15 dapat dilihat hasil dari daya yang didapatkan dengan pengujian klip kertas, beban paku, dan tanpa beban, dapat dilihat bahwa daya yang didapat pada pengujiam klip kertas dan paku mengalami penurunan dengan lamanya waktu dan daya yang didapat dengan menggunakan pengujian tanpa beban hanya mengalami sedikit penurunan dan konstan, dapat diartikan bahwa pengujian daya yang didapat dengan tanpa beban mendapatkan tegangan yang cukup konstan seiring tanpa adanya beban yang digunakan terhadap waktu pemanasan. 


\section{KESIMPULAN}

1. Pemanas induksi yang dirancang telah diujikan pada beban klip kertas dan paku yang dapat bekerja pada frekuensi resonansi sebesar $25 \mathrm{kHz}$.

2. Pengujian pemanas induksi pada beban klip kertas rata-rata kenaikan suhu pada detik ke-30 sebesar $51,5^{\circ} \mathrm{C}$ dan kenaikan suhu rata-ratasebesar 134,5 ${ }^{\circ} \mathrm{C}$ pada detik ke-600. Sedangkan untukbeban paku didapatkan hasildengan rata-rata kenaikan suhu pada detik ke-30 sebesar $63,5{ }^{\circ} \mathrm{C}$ dan kenaikan suhu rata-ratasebesar $136{ }^{\circ} \mathrm{C}$ pada detik ke-360.

3. Energi panas yang di dapat dari pemanas induksi ini adalah $\mathrm{Q}=19,5 \mathrm{~J}$ dengan waktu 600 detik untuk beban klip kertas, tegangan $3,33 \mathrm{~V}$, arus 0,15 A dan daya yang dihasilkan 0,65 watt.Sedangkan $\mathrm{Q}=33,6 \mathrm{~J}$ dengan waktu 360 detik untuk beban paku, tegangan $4,54 \mathrm{~V}$, arus 0,27 A dan daya yang dihasilkan1,12 watt, dengan pengujian kenaikan suhu. Sedangkan $\mathrm{Q}=15,9 \mathrm{~J}$ dengan waktu 600 detik untuk beban klip kertas, tegangan $3,33 \mathrm{~V}$, arus $0,15 \mathrm{~A}$ dan daya yang dihasilkan 0,53 watt. Sedangkan $\mathrm{Q}=34,5 \mathrm{~J}$ dengan waktu 360 detik untuk beban paku, tegangan 4,54 $\mathrm{V}$, arus $0,27 \mathrm{~A}$ dan daya yang dihasilkan 1,15 watt untuk pengujian tegangan, arus dan daya

\section{REFERENSI}

[1] R.Ismail, Jamari, M. Tauviqirrahman, dan A. Syakur, 2010, Pengembangan dan Penerapan Mesin Pemanas Induksi untuk Pengerasan Permukaan Roda Gigi Produk UKM.

Laporan Akhir Tahun Hibah Strategis Nasional DIKTI, 2010.

[2] Rio dery Alem, Eny. 2015 Inverter frekuensi tinggi sebagai pemanas piringan logam dengan metode induksi pada aplikasi pemanas roti Universitas Diponegoro : Semarang

[3] Mahardika, T. (2012).Perancangan Inver-ter Full Bridge Resonansi Seri Frekuensi Tinggi Untuk Aplikasi Induction Cooker.Semarang Universitas Diponegoro.

[4] Zhulkarnaen, Y. (2014) Perancangan dan Pembuatan Pemanas Induksi De-ngan Metode Pancake Coil Ber-basis Mikrokontroller
Atmega 8535. Malang: Universitas Brawijaya.

[5] V. Rudnev, D. Loveless, R. Cook dan M. Black, 2003, Handbook of Induction Heating, Marcel Dekker Inc., USA.

[6] E. Bowyer, 1987, Practical Heat Treating, American Society for Metal (ASM), Ohio, US.

[7] Taufik, Ardian Ramadhana. 2015, Perancangan Inverter Jembatan Penuh dengan filter seriparalel Frekuensi tinggi untuk aplikasi lampu led, Universitas Diponegoro : Semarang

[8] Noviansyah, R. (2012). Pemanas Induksi (Induction Heating) Kapasitas 200 Watt. Cimanggis: Universitas Gunadarma.

[9] Rachmadi, T. (2014) Realisasi Modul Inver-ter Full Bridge Menggunakan MOSFET IRFP460 Pada Aplikasi Pemanas Induksi Semarang: Universitas Diponegoro.

[10] Raharjo, P. (2013). Rancang Bangun Pemanas Induksi Berkapasitas $600 \mathrm{~W}$ Untuk Proses Perlakuan Panas dan Perlakuan Permu-kaan. Surakarta: Universitas Se-belas Maret (UNS).

[11] N. Mohan and T. M. Undeland, Power Electronics: Converters, Applications, and Design, 2nd ed. United States of America: John Wiley and Sons, Inc., 1989.

[12] Zuhal. 1988. Dasar Tenaga Listrik Dan Elektronika Daya. PT Gramedia Pustaka Utama: Jakarta

[13] Rashid, Muhammad H. 1993. Power Electronics Circuit, Devices, and Applications, Second Edition,. Prentice-Hall International: London

[14] Roberts, M.R MC. 2009. Getting Started With Arduino. USA

[15] Yohan Fajar Sidik, F. Danang Wijaya, Eka Firmansyah. 2013 Sinusoidal Pulse Width Modulation Berbasis Lookup Table untuk Inverter Satu Fase Menggunakan 16Bit Digital Signal Controller

[16] Bijoyprakash Majhi. 2012 Analysis of SinglePhase SPWM Inverter. Department of Electrical Engineering National Institute of Technology, Rourkela

[17] Rencono A. Wati. 2000. Desain Dan Analisa Pemanas Induksi. UKS: Semarang 